Fellow in physics; Dr. I. Hawkes, to be lecturer in the Postgraduate School of Mining; Dr. C. J. Ball, to be lecturer in metallurgy; I. Livingstone, to be lecturer in economic statistics; P. E. Brown, to be senior lecturer in preventive medicine and public health; W. T. Baker, to be health physicist.

\section{The Night Sky in August}

New moon occurs on Aug. 11d. 10h. 36m. U.T. and full moon on Aug. 26d. 03h. 14m. The following conjunctions with the Moon take place: Aug. 5d. 17h., Aldebaran 0.3 ${ }^{\circ}$ S.; Aug. 7d. 18h., Venus $3^{\circ}$ N.; Aug. 14d. 18h., Mars $2^{\circ}$ S.; Aug. 23d. 15h., Saturn $3^{\circ}$ S.; Aug. 23d. 23h., Jupiter $3^{\circ} \mathrm{S}$. In addition to these conjunctions with the Moon, Venus is in conjunction with Pollux on Aug. 24d. 1lh., Venus being $7^{\circ} \mathrm{S}$. There will be an annular eclipse of the Sun on Aug. 11, invisible at Greenwich. There will be a partial eclipse of the Moon on Aug. 26, visible at Greenwich. The Moon enters penumbra at $0 \mathrm{~h}$. $36 \cdot 1 \mathrm{~m}$., enters umbra at $1 \mathrm{~h} .34 .9 \mathrm{~m}$., leaves umbra at $4 \mathrm{~h} .41 \cdot 5 \mathrm{~m}$., and penumbra at $5 \mathrm{~h} .40 \cdot 4 \mathrm{~m}$., the magnitude of the eclipse being 0.992 . Moonset at Greenwich on Aug. 26 is at $5 \mathrm{~h} .11 \mathrm{~m}$. Mercury is too close to the Sun for observation. Venus is a morning star, rising at $1 \mathrm{~h} .05 \mathrm{~m}$., $1 \mathrm{~h} .15 \mathrm{~m}$., and $1 \mathrm{~h} .50 \mathrm{~m}$. on Aug. 1, 15 and 31, respectively. Its stellar magnitude on Aug. 15 is -3.5 ; the visible portion of the apparent disk increases from 0.683 to 0.792 during the month and its distance from the Earth increases from 96 to 115 million miles. Mars is too close to the Sun for observation. Jupiter sets at $3 \mathrm{~h} .50 \mathrm{~m} ., 2 \mathrm{~h}$. $40 \mathrm{~m}$. and $1 \mathrm{~h} .30 \mathrm{~m}$. at the beginning, middle and end of the month, respectively. It is near the border of Sagittarius and Capricornus; its stellar magnitude on Aug. 15 is $-2 \cdot 3$ and its distance from the Earth 385 million miles. Saturn sets at $3 \mathrm{~h} .20 \mathrm{~m} ., 2 \mathrm{~h} .15 \mathrm{~m}$. and 1h. 10m. on Aug. 1, 15 and 31, respectively. It is in Sagittarius; its stellar magnitude on Aug. 15 is +0.4 and its distance from the Earth is 845 million miles. There are no occultations of stars brighter than magnitude 6 visible at Greenwich. The Perseid meteors are active during the first half of the month. Maximum activity occurs on Aug. 12, the radiant is at R.A. + 3h. 04m., Dec. $+58^{\circ}$, and conditions for observation are very favourable.

\section{Announcements}

Dr. Arno Sigvard EkuUnd, of Sweden, has been appointed director-general of the International Atomic Energy Agency, in succession to Mr. Sterling Cole, whose four-year term of office ends on November 30, 1961. Dr. Eklund was secretary-general of the second United Nations Geneva Conference on the Peaceful Uses of Atomic Energy in 1958, and is chairman of the international board of management of the Organization for European Economic Co-operation High-Temperature Reactor Project Dragon at Winfrith Heath, Dorset.

Dr. Morten Srmonsen, lecturer in immunology, University of Copenhagen, has been appointed director of research at the McIndoe Memorial Research Unit, Queen Victoria Hospital, East Grinstead, Sussex, which is devoted to the study of tissue transplantation and associated problems of wound healing.

Mr. J. P. Catchpole, of the Department of Chemical Engineering, University of Birmingham, has been awarded the student's prize of the Institution of Chemical Engineers, for his paper entitled "Frequency Response Techniques for the Study of Packed Bed Characteristics". This is the first award of this prize, which is open to student members of the Institution of at least six months standing at the time of presentation or publication of the paper.

Arthur Guinness Son and Co., LTd., have established a scheme of awards of cash prizes totalling up to $£ 500$, to be called the Guinness Awards for Science Teachers in Training. The scheme is administered by The Science Teacher, the editorial director of which, Mr. Maurice Goldsmith, is chairman of the Guinness Awards Advisory Committee. The object of the scheme is to encourage students in teacher-training to develop and report on their own original contributions to the pedagogy of science in all its branches. The scheme will begin to operate as from September 1961. Further information can be obtained from the Information Office, Arthur Guinness Son and Co. (Park Royal), Ltd., Berk House, 8, Baker Street, London, W.1.

AN international congress of aviation and cosmonautical medicine is being held in Paris during September 26-30. Further information can be obtained from the secretariat, C.E.R.M.A., 5bis avenue de la Porte de Sèvres, Paris, France.

THE Faraday Society has arranged a general discussion on "The Structure and Properties of Ionic Melts" which will be held in the Department of Inorganic and Physical Chemistry, University of Liverpool, during September 5-7. Further information is available from the Secretary, Faraday Society, 6 Gray's Inn. Square, London, W.C.1.

THE sixth annual conference of the British Society for the Philosophy of Science is being held at St. Hugh's College, Oxford, during September 22-24. The following are included in the programme: explanation in psychology; learning machines; genetic coding and information theory; statements about the universe. Further information can be obtained from Dr. M. B. Hesse, Whipple Museum, Free School Lane, Cambridge.

THe First International Conference on Timber Engineering will be held in the University of Southampton during September 18-23. General problems of timber construction, structural timber joints, structures of particular interest, testing of timber structures, timber shell structures, constructional problems and economics and comparisons are the main subjects which will be discussed. Further information can be obtained from Dr. H. G. Allen, Department of Civil Engineering, University, Southampton.

A serIEs of postgraduate full-time courses is to be held in the Nuclear Studies Section of the Department of Chemistry and Biology, Liverpool College of Technology, during the 1961-62 session. These include a seven-months course in radiation safety and health physics, a number of two-week courses in radiation safety, radiobiology and radiochemistry, and a one-week course in radiation chemistry. Further information can be obtained from the Principal Lecturer and Organizer in charge of Nuclear Studies, Chemistry and Biology Department, College of Technology, Byrom Street, Liverpool 3. 